\title{
Editorial: E. J. Lowe's Metaphysics and Philosophical Theology
}

\author{
MIHRETU P. GUTA
}

Biola University, Addis Ababa University E Azusa Pacific University

The Center for Bioethics and Human Dignity, Trinity International University

mihretu.p.guta@biola.edu

\section{ERIC LAROCK \\ Oakland University $\mathcal{E}$ Center for Consciousness Science, University of Michigan larockconsciousness@gmail.com}

Edward Jonathan Lowe was one of the most distinguished metaphysicians of the last 50 plus years. He made immense contributions to analytic philosophy in as diverse areas as metaphysics, philosophy of mind, philosophy of language, philosophical logic, history of Modern philosophy (especially on John Locke), and philosophy of religion.

Lowe was a realist metaphysician. Like Aristotle, he thought that, with sustained reflection and responsible engagement with empirical research, the nature of a mindindependent reality can be discovered. In all of his works, Lowe consistently maintained that our common-sense pre-philosophical convictions about reality should not be ignored unless there is a good reason to do so. Even in such cases, Lowe firmly believed that common sense should rather be corrected and further enriched in light of relevant empirical discoveries. But Lowe never accepted the idea that, in light of the advancement of science, somehow we should entirely stop our reliance on common sense in our inquiry into the nature of reality. Partly in defense of this very view, Lowe developed his most influential and highly original work: the four-category ontology. The gist of this work concerns metaphysics as an inquiry into the structure of ultimate reality (taken in general), which provides a foundation for natural science. Lowe strongly believed that it is metaphysics, not science that can set the terms for what is possible and not possible. Lowe believed that figuring out what actually exists in the natural world falls within the purview of science. In Lowe's view, metaphysics and science can and should work in synergy, each playing its distinctive role in enhancing our knowledge of a mind-independent reality. Lowe extended his realist view of reality to causation, laws of nature, modality, personal identity, logic, language, God's existence, time and space, human ontology, properties, and many other issues.

The impact of Lowe's work on metaphysics continues to be a subject of immense interest to philosophers. For example, in this regard, we can mention some of the recent high-level publications on Lowe's metaphysics, namely: E. J. Lowe and Ontology 
edited by Miroslaw Szatkowski (Routledge, 2022); Ontology, Modality E Mind: Themes from the Metaphysics of E.J. Lowe edited by Alexander Carruth, Sophie Gibb, and John Heil (OUP, 2018); Studies in the Ontology of E.J. Lowe edited by Timothy Tambassi (Editiones Scholasticae, 2018).

Lowe's views on ontological issues also have direct implications for issues in philosophical theology as well as a philosophy of religion such as the incarnation, trinity, divine attributes, human agency, and divine sovereignty, unified experience and the existence of God, divine causation, divine temporality or atemporality, just to mention a few. One of the things that makes Lowe's work uniquely suitable to apply to various issues in either philosophical theology or philosophy of religion has to do with its systematic nature. Lowe built an extremely sophisticated ontological system as shown in his The Four-Category Ontology. In so many ways, Lowe's highly original ontological system will prove relevant to address questions that arise both in philosophical theology and in philosophy of religion. Many contemporary metaphysicians who are influenced by Lowe's system have an interest to integrate elements of Lowe's metaphysics in their treatment of these questions.

Yet, to this date, no attempt has been made to take a general look at how Lowe's metaphysics relates to various issues in philosophical theology as well as in philosophy of religion. This is the first attempt to take concrete steps to fill in the existing gap in this regard. To this effect, each of the papers in this special issue applies the relevant aspects of Lowe's metaphysics and ontology to different theological issues.

In "An Embodied Existence in Heaven and the Non-Cartesian Substance Dualism (Revisited)" Alejandro Pérez proposes to imagine, through Lowe's Non-Cartesian substance dualism (NCSD), how it is possible to resurrect. Despite many objections raised against the classic conception of eschatology (i.e., the history of end times), Pérez argues that there are some reasons to think that a more corporeal conception of the eschaton is desirable which he claims is also metaphysically possible. As Pérez further shows, a corporeal conception of the eschaton is compatible with biblical data. Pérez advances his discussion by exploring what he calls the Christ Body Argument. Pérez claims that the Christ Body Argument invites us to reject a disembodied existence in heaven. Alternatively, this argument gives us reasons to adopt the corporeal existence of Christ in heaven. Pérez claims that a kind of Dualism, that is, one possessing Lowe's NCSD's virtues, could play a role in exploring this new theological option. Pérez considers Lowe's NCSD as a metaphysical option which he says helps us to better understand what we are. Pérez claims that if we hope and believe in the resurrection of the dead, Lowe's NCSD provides us with an interesting model to think about it.

In "Craig's Anti-Platonism, Lowe's Universals, and Christ's Penal Substitutionary Atonement", R. Scott Smith looks at William Lane Craig's account of nominalism which he takes to be a kind of "anti-Platonism." Scott claims that for Craig, Platonism is inimical to God's aseity (i.e. necessarily self-existent being). Craig, more recently, also defended the penal substitution of Christ (i.e., Christ death as a substitute for 
sinners). Scott claims that Craig has not brought the two subjects into dialogue with each other. So in this essay, Scott wants to rectify what he thinks is lacking in Craig's work. Scott attempts to do this by exploring the implications of austere nominalism and trope theory, for the penal substitution. Scott argues that nominalism undermines the penal substitution of Christ. In light of such observations, Scott argues that for Craig to preserve both his anti-Platonism and the penal substitution, a better alternative is to embrace E. J. Lowe's immanent universals.

In "Monarchical Trinitarianism: A Metaphysical Proposal", Joshua R. Sijuwade aims to provide a metaphysical elucidation of a specific model of the doctrine of the Trinity. He calls this model Monarchical Trinitarianism. Sijuwade discusses Monarchical Trinitarianism, within Lowe's formal, neo-Aristotelian ontological and metaphysical framework. In this regard, Sijuwade focuses on Lowe's four-category ontology and serious essentialism. Sijuwade shows how formulating the Monarchical Trinitarianism model through Lowe's ontological and metaphysical framework will enable us to clearly explicate it. Moreover, Sijuwade argues that by applying Lowe's ontological and metaphysical framework, the important 'multiple-natures' problem raised against the Monarchical Trinitarianism model can be shown to be ineffective.

In "The Five-Category Ontology? E.J. Lowe and the Ontology of the Divine", Graham Renz argues that although Lowe was a theistically-inclined philosopher who developed and defended a four-category ontology with roots in Aristotle's Categories, he engaged in little philosophical theology. Renz further argues that Lowe said even less about how a divine being might fit into his considered ontology. So in this essay, Renz explores ways in which the reality of a divine being might be squared with Lowe's ontology. Renz motivates the exploration with a puzzle that forces Lowe to reject either divine aseity or the traditional view that God is a substance. Renz shows that the puzzle cannot be overcome by rejecting one of its premises. In light of this, Renz considers ways in which Lowe might try to reject the puzzle in its entirety. Renz argues that the best way to reject the puzzle is to countenance a fifth fundamental category which he describes as the category of supernatural substance.

In "From Murphy's Christian Physicalism to Lowe's Dualism", Mostyn Jones and Eric LaRock discuss Nancey Murphy's physicalism according to which God created us as physical beings without immortal souls. Murphy draws her main justification for her Christian physicalism from neuroscience, which she claims can better explain minds in terms of physical information processing than the problematic dualists' account of nonphysical terms. However, Jones and LaRock argue that Murphy overestimates the role of neuroscience and in doing so, unjustifiably underestimates dualism. Jones and LaRock further argue that Murphy fails to show how neuroscience can explain the features of the mind such as qualia, unity, privacy, and causality. By contrast, Jones and LaRock argue that Lowe's dualism can better explain the features of the mind in experimentally testable ways. In light of this, Jones and LaRock argue that the inadequacy of Murphy's physicalism further amplifies the value of Lowe's dualism. 
In "Metaphysics, Natural Science and Theological Claims: E. J. Lowe's Approach", Mihretu P. Guta discusses Lowe's view of the synergy between metaphysics and natural science. In doing so, he extends Lowe's synergistic model to develop a realist account of theological claims thereby responding to Peter Byrne's strong form of eliminativism and agnosticism about theological claims. Guta begins his discussion with Lowe's view of metaphysics in which he shows how Lowe thinks metaphysics and natural science are related. After responding to objections against Lowe's conception of metaphysics, Guta discusses the implications of Lowe's conception of metaphysics for a realist account of theological claims. He ends his discussion by claiming that there are excellent reasons to extend the synergy between metaphysics and natural science to that of theology as well.

Finally, in "E. J. Lowe and Divine Causal Agency", Gregory E. Ganssle applies Lowe's theory of rational agency to God's causal activity. Ganssle argues that Lowe's account fits well the traditional notions that God acts in the world for reasons. In contrast to Lowe's analysis of human causal agency, Ganssle argues that in the divine case, reasons for acting are not constituted by needs. Rather reasons for acting are constituted by God's desires or plans. As Ganssle sees it, the fit between Lowe's account of causal agency and the contours of divine causal agency motivates an argument in favor of Lowe's theory of rational agency. Ganssle ends his essay by claiming that any philosopher who is a theist ought to think Lowe's account is likely to be true.

\section{Bibliography}

Carruth, Alexander, Gibb Sophie, and John Heil (eds.). (2018). Ontology, Modality $\mathcal{E}$ Mind: Themes from the Metaphysics of E.J. Lowe. Oxford University Press. https://doi.org/10.1093/oso/9780198796299.001.0001.

Guta, Mihretu P. (2014). “Professor E. J. Lowe (1950-2014)". Teorema: Revista Internacional de Filosofía Vol. 33, No. 1 (2014), pp. 159-162.

Miller, J. T. M. 2021. "Edward Jonathan Lowe (1950-2014)," in The Internet Encyclopedia of Philosophy. https://iep.utm.edu/lowe-ej/.

Lowe, E.J. (2006). The Four-Category Ontology: A Metaphysical Foundations for Natural Science. New York: Oxford University Press.

Szatkowski, Miroslaw (ed.). (2022). E. J. Lowe and Ontology. Routledge.

Tambassi, Timothy (ed.). (2018). Studies in the Ontology of E.J. Lowe. Editiones Scholasticae. 